\title{
A Gramscian Study of Ideology and Hegemony in Amiri Baraka play: The Dutchman
}

\author{
Shiva Zaheri Birgani ${ }^{1}$, Maryam Jafari ${ }^{2}$ \\ ${ }^{1}$ Islamic Azad University, Masjed Soleyman, Khuzestan Province, Iran \\ ${ }^{2}$ Islamic Azad University, Science and Research Branch, Tehran, Iran \\ shvzaheri@gmail.com
}

\begin{abstract}
This paper attempts to investigate significations of the tropes of whiteness and blackness in white American culture in Baraka's play, The Dutchman. . Gramsci is concerned with how one views man in history. His point is that men determine history rather than the reverse and this history is determined by the way in which men produce their means of subsistence. Man therefore is a social and "material" entity since. By producing their means of subsistence men are indirectly producing their actual material life. Man's ability to produce, the means of production, and the product produced, therefore, are central to man's ability to be self-determined, to be real rather than an abstraction, a concept. It is in man's reality, a reification brought about by the conscious act of production that he establishes his humanity. Marx's humanism, therefore, is social in that man produces for more than himself; it is material in the "mode of production." By material is not meant "psychic motivation" towards material goods. Based on the Gramsci hegemony, the black man has no history, he must create it; more importantly, since, according to Baraka, "Negro Literature" can never emerge from black consciousness unless it separates itself from the pre-established conditions, the literature must create and define itself in the process of becoming.
\end{abstract}

\section{Keywords}

hegemony; ideology; civil society

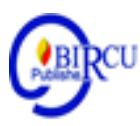

\section{Introduction}

Amiri Baraka is a Newark-born, Howard-educated playwright, poet, and essayist. As LeRoi Jones, he began his career as part of the downtown beat movement in the late 1950s and early 1960s. His work was always built on the rhythms of African American music and language, but did not emphasize confrontation with whites until 1964, when his plays Dutchman and The Slave were first produced. In 1965 he left his Jewish wife, published his seminal essay "The Revolutionary Theatre," and co-founded the Black Arts Repertory, which became the center of the separatist Black Arts movement. In the later 1960s he took the Muslim name Amiri Baraka, remained active in both political and artistic movements concerned with Black independence, and produced a number of plays, notably Slave Ship (1967). According to Gramsci, All objections urged against the Communist mode of producing and appropriating intellectual products. Just as, to the bourgeois, the disappearance of class property is the disappearance of production itself, so the disappearance of class culture is to him identical with the disappearance of all culture. Your very ideas are but the outgrowth of the conditions of your bourgeois production and bourgeois property (Hegemony 29). 


\section{Research Methods}

The concept of hegemony first appeared in Gramsci's Notes on the Southern Question (1926), where it was defined as a system of class alliance in which a "hegemonic class" exercised political leadership over "subaltern classes" by "winning them over." The concept made allusion to the proletariat in Italy in terms of such a "winning over": the proletariat had to free itself of its class corporatism so as to embrace other classes, notably the peasants, in a system of alliances within which it could then genuinely become the leading element in the society. The concept was introduced in the following way:

The Turin communists posed concretely the question of the 'hegemony of the proletariat': i.e. of the social basis of the proletarian dictatorship and the workers' State. The proletariat can become the leading (dirigent) and the dominant class to the extent that it succeeds in creating a system of alliances which allows it to mobilize the majority of the working population against capitalism and the bourgeois State. In Italy, in the real class relations which exists there, this means to the extent that it succeeds in gaining the consent of the broad peasant masses.[1]

As presented to us here the concept is in a relatively primitive stage. It is in the Prison Notebooks that Gramsci presents us with an advanced definition of the concept, this time going beyond a simple class alliance and political leadership by including intellectual and moral leadership and elaborating on the process of forging the class alliance. Hence, in the more developed elaboration "Hegemony" entails two things. First of all, it presupposes that the "hegemonic class" takes into consideration the interests of the classes and groups over which it exercises its "hegemony." Added to this, some equilibrium between the hegemonic class and the subaltern classes is entailed whereby the hegemonic class will be forced to make some sacrifices tangent to its corporate interests. Secondly, "hegemony" entails economic leadership besides ethico-political leadership. In other words, it entails that the hegemonic class be a "fundamental class"-that is, a class situated at one of the two fundamental poles in the relations of production: owner or non-owner of the means of production. It would seem, therefore, that hegemony entails for a class its execution of a leadership role on the economic, political, moral, and intellectual levels vis-a-vis other classes in the system, coupled with the sacrificing of some of its corporate interests as a fundamental class precisely to facilitate its vanguard role. Noticeable in this notion is the abstract notion of balance: sacrifice for consensus or strict corporativism for a coercive imperative. Indeed, this notion underlies Gramsci's definition of the concept of hegemony, and the notion itself is embodied in Gramsci's elaborate concept of power.

Gramsci's concept of power is based simply on the two moments of power relationsDominio (or coercion) and Direzione (or consensus). These two moments are essential elements, indeed the constitutive elements of a state of balance, a state of equilibrium between social forces identified as the leaders and the led. This state of balance consists of a coalition of classes constituting an organic totality within which the use of force is risky unless there emerges an organic crisis which threatens the hegemonic position and the ruling position of the leading class in the hegemonic system. Clearly, political or state rule by a hegemonic class so defined would be rule in which consensus predominates over coercion. According to Gramsci, consensus rests at the level of civil society and hence must be won there. On the other hand, coercion rests at the level of the state, more specifically at the level of "political society." Accordingly, hegemonic rule, characterized by the predominance of consensus over coercion, represents in broad terms a balance, an equilibrium between "political society" and "civil society." Needless to say, for Gramsci the state embodies "the 
hegemony of one social group over the whole of society exercised through so-called private organizations, such as the church, trade unions, schools, etc.,"[2] in balance with the ensemble of public (coercive) organizations such as the state, the bureaucracy, the military, the police, and the courts. Thus, state power rests in a hegemonic equilibrium with alternated moments of force and consensus but without the necessity of predominance by coercion over consensus.

Gramsci's contribution to Marxist theory is two-fold. On the one hand, with concepts such as "organic ideology," "civil society" and "political society," "organic intellectuals," "hegemony," etc., as well as his unique distinction between political society and civil society, Gramsci brought new theoretical foundations into truly dialectical Marxist revolutionary theory. Most important, out of these foundations emerged new concepts that have given Marxism more consistency and relevance vis-a-vis contemporary Capitalist reality. It is safe to argue, for example, that Althusser's notion of "ideological state apparatuses" evolves out of Gramsci's general concept of civil society and ideological structures therein serving as the social pillars of state power.

\section{Discussion}

\subsection{Superstructure in Civil Society}

The Dutchman, a play which centers around two characters on a subway, a black man and a white woman, is still perhaps the most powerful statement on racism, class conflict, and alienation (as symbolized by an interracial couple) and society's attitude toward such issues (as symbolized by its attitude toward the couple) available in drama today. Clay, a middleclass black man, and Lula, a pseudo-middle-class white woman discover each other through confrontation. It is a confrontation evolving out of a sense of alienation and despair and desperation. They are obsessed with the need to combat each other both spiritually and sexually, with only Lula knowing the possible results of such a battle. Clay wants to put Lula to bed; Lula wants to put Clay to rest.

The play therefore is one which "moves" due to lack of perception. It is an exercise in stasis, but one which is totally destructive. From the beginning of their "involvement" on the subway Lula warns Clay about her capacity for lying:

LULA: You look like you been trying to grow a beard.

CLAY: Really? I look like...that

LULA: Not at all. [She feigns a seriousness to cover an actual somber tone.]

I lie a lot [smiling].

It helps me control the world (8).

Baraka never grasps the full impact of Lula's words, but they serve as a tantalizing reality for him. If he really believes her, i.e., thinks she lies, then he has no choice but to leave her alone on the subway. If he distrusts her then the response is still the same. Clay chooses to believe both. He believes she's lying when she talks about his looks and living in a tenement but telling the truth when she says that she will go to bed with him. In choosing both realities Clay loses his position of alienation, regardless of how weak it is, and is catapulted into the world of Lula, the worlds of racism, class conflict, and sex. It may seem ironic to speak of alienation as a position of "safety," but at this stage in the play, Baraka indicates that to be accepted into Lula's world is not good. If you are kept out, in an ironic way, you are less vulnerable. Lula goads Clay into a confrontation by constantly fluctuating back and forth between seductress and angry bitch. 
CLAY : Are you angry about anything? Did I say something wrong?

LULA : Everything you say is wrong. [Mock smile] That's what makes you so attractive. Ha. In that funnybook jacket with all the buttons. [More animate, taking hold o f his jacketl What've you got that jacket and tieon in all this heat for? And why're you wearing a jacket and tie like that? Did your people ever bum witches or start revolutions over the price of tea? Boy, those narrow-shoulder clothes come from a tradition you ought to feel oppressed by. A three-button suit. What right do you have to be wearing a three-button suit and striped tie? Your grandfather was a slave, he didn't go to Harvard.

CLAY : My grandfather was a night watchman.

LULA : And you went to a colored college where everybody thought they were Averell Harriman.

CLAY : All except me.

LULA : And who did you think you were? Who do you think you are now?

CLAY : [Laughs as if to make light of the whole trend of the conversationl. Well, in college I thought I was Baudelaire. But I've slowed down since.

LULA : I bet you never once thought you were a black nigger. [Mock serious, then she howls with laughter. CLAY is stunned but after initial reaction, he quickly tries to appreciate the humor.

LULA almost shrieks] A black Baudelaire.]

What Lula accomplishes in this incredible dialogue is a systematic "deflowering" of Clay, and I use this term purposefully because Lula is the aggressor, the woman in search of a real man. In the above dialogue, Lula attacks Clay's ancestry, his social position and class, his art, his education and his manhood. There is not much Clay left. He begins on the alienation level of indifference and ends through Lula's hands, on the "sub-level" of death and despair. What is crucial to understand relative to Lula's attack on Clay is that she is spouting the Hegemony line preached to so many blacks during the fifties and sixties. The "party line" of social, economic, and political justice founded on a cataloging of dehumanizing practices against blacks was what made Hegemonic so appealing to them during the struggle for civil rights.

Baraka states therefore, that Lula is either a lower class white, or is desirous to pretend to be one "Hugged against tenements, day or night" (p. 13) so that she can ferret out those blacks which history has taught her to be suspicious of, i.e., blacks with a proletarian spontaneous energy, political and sexual, dressed in a bourgeois facade. Lula's suspicions about Clay and the areas in which she confronts him are numerous:

1) Self-Recognition:

LULA : Weren't you staring at me through the window? At the last stop?

CLAY : Staring at you? What do you mean?

LULA : Don't you know what staring means?

CLAY : I saw you through the window.. .if that's what it means. I don't know if I was staring. Seems to me you were staring through the window at me.

LULA : I was. but only after I'd turned around and saw you staring through the window down in the vicinity of my ass and legs. (pp. 6-7)

2) Sex:

LULA : You think I want to pick you up, get you to take me some where and screw me huh? (p. 8). 
LULA : [Putting her hand on Clay's closest knee, drawing it from the knee up to the thigh's hinge, then removing it, watching his face very closely and continuing to laugh, perhaps more gentle than before] Dull, dull, dull, I bet you think I'm exciting.

CLAY : You're O.K.

LULA : Am I exciting you now? (p. 10).

3) Politics:

LULA : Although my mother was a communist. The only person in my family ever to amount to anything.

CLAY : My mother was a Republican

LULA : And your father voted for the man rather than the party... And yea for American where he is free to vote for the mediocrity of his choice. Yea! (pp. 20-21)

4.) Race: Racism:

LULA I bet you never once thought you were a black nigger. [Mock serious, then she howls with laughter. CLAY is stunned but after initial reaction, he quickly tries to appreciate the humor. LULA almost shreiks] A black Baudelaire, (p. 19).

Many other instances can be cited in which Lula goads Clay into a defensive posture, usually one in which he must reveal his true feelings in order to answer her charges and then she seemingly relents and moves into other areas of confrontation. Skillfully, she strips Clay of his sense of his blackness and leaves him naked for the world to mock in his shrinking manhood, which as Lula states "we've been talking about all this time... (p. 25)

Baraka provides a clue to this deflowering of Clay in his essay "american sexual reference: black male" in Home. He states:

The reason the white woman was supposed to be intrigued by the black man was because he was basic and elemental emotionally (which is true for the non-brainwashed black, simply because there is no reason he should not be; the black man is more "natural" than the white simply because he has fewer things between him and reality, fewer wrappers, fewer artificial rules), therefore "wilder," harder, and almost insatiable in his love making (pp. 222-223).

Lula, therefore, by confronting Clay on various issues, is stripping Clay down to basics, so to speak, and is trying to discover just how brainwashed he is and how many layers of artificial rules he has wrapped himself in. What she uncovers, unfortunately, frightens her. Suffice it to say, this essay is rich with allusions to the play and ideas that Baraka incorporated within the plot. There are three which should be documented in concluding this review of The Dutchman.

1) For the black man, acquisition of a white woman always signified some special power the black man had managed to obtain (illicitly, therefore with a sweeter satisfaction) within white society. It was also a way of participating more directly in white society. One very heavy entrance into white America, (p. 223).

2) The black man is weakened by any friend-contact with whites simply because his concerns will shift ...and the raw problems of survivalmindsoulbody- will be obfuscated, and replaced by unwhite hallucinations. That is, such a black man can be taught by his new environment, to imitate the needs of people who have not the same sources as he, who have not the same needs, who, finally, are the same white people whose murders are being plotted by 90 percent of the world... (p. 225).

3) The blackman, then, because he can enter into the sex act with less guilt as to results, is freer. Because of the robbery/rape syndrome, the black man will take the white woman in a way that does not support the myth of The Lady...But also, the "liberated" white man is 
more aware of his culture's deficiencies and ugliness... Jack Kerouac's virtuous, mysterious, sensual black is drawn from his conscious/unconscious understanding that the white man is evil withdrawal from the sweetest feelings in life. (p. 228).

These passages point out one incredible motivation of the play which helps to understand the characters Clay and Lula. Clay is motivated by the thought and smell of sex, but disguises it in social convention: small talk, polite behavior, and passive participation. Lula is motivated by race and class to gain power, and disguises her intentions through sexual deviant behavior. What frightens her is a sense that Clay is also stripping her of her facade, thus he knows more about her than she him. As she confronts him on all levels at once goading him further into nakedness, she likewise reveals her own weaknesses:

LULA: Come on Clay... let's do the thing. Uhh! Uhh! Clay! Clay! You middle-class black bastard. Forget your social-working mother for a few seconds and let's knock stomachs. Clay, you liver-lipped white man. You would-be Christian. You ain't no nigger, you've just a dirty white man. Get up, Clay. Dance with me, Clay. (p. 31)

Lula, exposed in all her hostility, Clay, shocked to his manhood about the price one must pay in order to bed the "symbol" of white liberation and oppression (as well as black liberation and oppression) now stand face to face as combatants in the real struggle of American history, race, sex, power, genocide. Lula and Clay have become that which they already were, and in the process have defined themselves and mirrored history. Lula's becoming is the liberation from the white male oppressive stereotyping of her combined with the true recognition that to unite with the black man is ultimately genocide. Clay's becoming is the knowledge that sex with white women is the trap of black bourgeois mentality and the destruction of his manhood. For Lula, her awareness is liberating; for Clay, Baraka suggests that such awareness acted upon is suicidal. Thus in the speech Clay gives after Lula's outburst cited above, Clay gives his own eulogy. In the process of allowing (letting her live) Lula to become and denying his own essence, Clay orchestrates his own death, his structural, political, aesthetical, religious, social, and existential suicides. He is truly alienated now from both worlds, from all existence. Knowledge for Clay, that knowledge which saves and enlightens, comes too late:

But listen, though, one more thing. And you tell this to your father, who's probably the kind of man who needs to know at once. So he can plan ahead. Tell him not to preach so much rationalism and cold logic to these niggers. Let them alone. Let them sing curses at you in code and see your filth as simple lack of style. Don't make the mistake, through some irresponsible surge of Christian charity, oftalking too much about the advantages of Western rationalism, or the great intellectual legacy of the white man, or maybe they'll begin to listen. And then, maybe one day, you'll find they actually do understand exactly what you are talking about, all these fantasy people. All these blues people. And on that day, as sure as shit, when you really believe you can "accept" them into your fold, as halfwhite trusties late of the subject peoples. With no more blues, except the very old ones, and not a watermelon in sight, the great missionary heart will have triumphed, and all of those ex-coons will be standup Western men, with eyes for clean hard useful lives, sober, pious and sane, and they'll murder you. They'll murder you, and have very rational explanations. Very much like your own. They'll cutmyour throats, and drag you out to the edge of your cities so the flesh can fall away from your bones, in sanitary isolation(10).

The ultimate irony of this speech, of which Clay can be truly proud, is that he does not know where or who he is. He is a pitiful black man on the subway going nowhere seemingly. He thinks he is a "together" con man who has attained the position of prophet and can now tell the rest of the world how to behave and what to believe. What he tells us in confidence is only how to die. In the true tragic sense, therefore, the masses gain knowledge, we now 
understand how society goads us into a behavior which it can then condemn and thus destroy us; but we gain that knowledge at the expense of the hero. Baraka would state in support of this theory that the deaths of Malcom X and Martin Luther King are clear examples of this process toward self-realization. In the overall concept of what it means to be black, Clay probably does not matter in the Barakian schema; by the same token, Baraka suggests that if one does exist, i.e., a black man who is heroic and lives, then he is not black. Baraka's homosexual in The Baptism, therefore, becomes an effete middle-class black man in The Dutchman. In some ways, Baraka labels them both as traitors in the Black world.

\subsection{Double Consciousness}

If Dutchman can be understood as an intimal conflict, a dream, it is a dream in which the binaries black and white, male and female, become contextualized in the individual psyche of one person. Blackness signifies in this text virtue and naYvet6; whiteness vice and disingenuousness. Maleness signifies castration, and femaleness phallic power. The text inverts the typical significations of the tropes of whiteness and blackness in white American culture. The relationship of these significations to the themes of incest and parricide, particularly patricide, is made clear by Clay:

CLAY [...]tell this to your father, who's probably the kind of man who needs to know at once. So he can plan ahead. Tell him not to preach so much rationalism and cold logic to these niggers. Let them alone.[...] Don't make the mistake, through some irresponsible surge of Christian charity, of talking too much about the advantages of Westem rationalism, or the great intellectual legacy of the white man, or maybe they'll begin to listen. And then, maybe one day, you'll find they actually do understand exactly what you are talking about, all these fantasy people.[...] And on that day, as sure as shit, when you really believe you can 'accept' them into your fold, as half-white trustees late of the subject peoples.[...] They'll murder you, and have very rational explanations. Very much like your own. They'll cut your throats, and drag you to the edge of your cities so the flesh can fall away from your bones, in sanitary isolation. (36).

Clay's desires are clear: he wants to murder the white father. The character Clay, himself a castrated, "half-white trustee," here reveals a vision of race revolution which will lead to an inversion of the dominant structure of power.

First he will purge the initialized whiteness from his own psyche (the seductive phallic mother, in Kristeva's terms), then murder the white father who controls the social structures of racial domination

Both acts of Dutchman are set in a New York subway car. In the course of the play passengers occasionally get on and off the train, but the focus is on the only two speaking characters, a college-age Black student named Clay and an attractive thirty-year old white woman named Lula. As the play opens, Lula sits down beside Clay and starts a conversation with him. From his dress and demeanor, she quickly (and to some extent correctly) reduces him to a cultural stereotype: he is a student from New Jersey, fancies himself a poet, and is on his way to a party to see a Black friend who affects an English accent. She begins to tease him seductively, first offering him an apple and finally inviting him to her tenement apartment to "do the nasty" and "rub bellies" with him (30). At the same time, however, she belittles him as a Black man, tossing at him racial epithets including "black nigger" (18), "escaped nigger" (29), and "Uncle Tom Big Lip" (33), and accusing him of using white culture to hide his Blackness even from himself. "What right do you have," she asks, "to be wearing a three-button suit and striped tie? Your grandfather was a slave, he didn't go to Harvard" (18-19). Her verbal assault builds to a feverish level of excitement, culminating with her accusation that Clay is "afraid of white people" (33). Until this point Clay has 
listened to Lula with remarkable passivity, responding with wry amusement to most of her antics. Now, however, he slaps her across the mouth as hard as he can, tells her to "shut up and let me talk" (33), and launches into a long, furious monologue in which he explains that his "white" demeanor, like the musical expressions o f blues and jazz artists, is "an a c $t$... to keep myself from cutting all your throats" (34). W hites, he says, who claim to love the blues "don't even understand that Bessie Smith is saying, "Kiss my ass, kiss my black unruly ass,", and that if she "had killed some white people she ... could have talked very straight and plain about the w orld" without burying her message in artistic metaphors (34-35). Eventually, he promises, once they have learned to kill, "all those ex-coons" will "murder you ... cut your throats, and drag you out to the edge of your cities so the flesh can fall away from your bones, in sanitary isolation" (36).

According to almost all feminist scholar's patriarchy refers to rule of the father in a male dominated society as a social and ideological construct which regards men as superior to women. They are of opinion that men's domination over female sexuality is central to women's subordination. In fact, man is the head of the family who controls women's sexuality, labor, production, reproduction and mobility. Moreover, the effect of patriarchy can be traced in politics, public life and economy as well as in all aspects of social, personal, psychological and sexual existence.(Raoufzadeh,60)

The play that linger outside the margins of the Western patriarchal canon-beyond illusory fantasies of pure, chaste, "before-the-fall" white womanhood (Davy 212). In Amiri Baraka's Dutchman the "phantasm" of white womanhood is appropriated in the "service" of black control and supremacy. Dyer writes: "the white male spirit achieves and maintains empire; the white female soul is associated with its demise" (67). Persecuted by fantasies of black revenge and Western romance, the black male protagonists in these works perceive the white woman as their ideal victim and lover. Lula, Dutchman's haunting white heroine, tells Clay right from the start: "I'm nothing, honey, and don't you forget it" (Baraka, Dutchman 19). Beth McCoy observes that "Lula is designed to be Dutchman's most visible, but not the most substantial, player" (55).

Basirizadeh in his article in title of A Comparative Study of the Psychoanalytical Portrayal of the Women Characters by Virginia Woolf and Zoya Pirzad states that, "They gauge the challenges to 'feminist knowledge' claims that are rooted in the "dominant approaches to science, reason, progress and truth" in relation to women's experience. Besides, the 'colonial and imperial history', and the 'uneven development of global capitalism' for them is rudimentary to such knowledge" (2).

Regarding Lula's dubiously symbolic role, Baraka writes: "she does not represent anything - she is one. And perhaps that thing is America, or at least its spirit" (Home 213). In Dutchman, the overruling white male is absent but eerily remains a threatening force. Wearied by his disillusionment, Clay ultimately decides that he'd rather play the "fool" as opposed to challenging the white patriarchal order (Baraka, Dutchman 37).

Basirizadeh in his article mentions that, "In de Beauvoir's view if women really want a status, they should deconstruct the structures of the masculine society and present their own definition of feminity. This definition would be the proof of woman's presence and existence counter-intuitive to masculine canon of knowledge in power"'(2).

Regarding Clay 's unconsummated dreams, my project primarily focuses on the white woman's role as "object of contention" between the white and black man (Zahlan 91). Black nationalist, Eldridge Cleaver, writes: "I don't know just how it works...but I know that the white man made the black woman the symbol of slavery and the white woman the symbol of freedom...men die for freedom, but black men die for white women, who are the symbol of freedom" (160). We see how the forbidden white woman becomes inextricably linked to the 
black male's existential desires. As a result, the forbidden whitewoman has become an integral figure in African American discourse, particularly inseminal works regarding black manhood (Dutchman).

It is shaped by the hegemonic concerns and fantasies of white men and Clay is inexorably caught in the language of white patriarchy. Though they desire black revenge, he can only identify themselves through an illusory white identity.

\section{Conclusion}

In conclusion, As Clay and Lula seemingly create each other, thus do the proletariat and the artist. And Baraka suggests that there is a consciousness of necessity which brings about such creativity. Baraka's Dutchman exposes the repressed "phobias and fears" of black men, but is also specifically reveals the anxieties of its creator the artist needs to exist; the proletariat needs his existence. Dutchman can be understood as an intimal conflict, a dream, it is a dream in which the binaries black and white, male and female, become contextualized in the individual psyche of one person. Blackness signifies in this play virtue Maleness signifies castration, and femaleness phallic power. The play inverts the typical significations of the tropes of whiteness and blackness in white American culture. The destruction of the bourgeois' language is accomplished through a dialectic, Marxist in intent, economic in form, and alienating in production. Success in developing such an aesthetics is dependent on making the proletariat whole, i.e., to eliminate the contradictions and the negations between the proletariat and his psyche.

\section{References}

Baraka, Amiri. (2014). "Advice to Young Writers: A Conversation with Amiri Baraka."NNOMO Literary Society workshop, New Orleans, 17 February 1998. Web. 2.Oct.

---. (1964). Dutchman and The Slave, Two Plays. New York: Morrow, 1964. ---. The Dead Lecturer; Poems. New York: Grove, 1964.

---. (2014). “The Revolutionary Theatre.” Liberator 3 (1965): 1-3. National Humanities Center.Web. 8 Sept.

Basirizadeh, Fatemeh. (2019). A Comparative Study of the Psychoanalytical Portrayal of the Women Charactersby Virginia Woolf and Zoya Pirzad. Britain International of Humanatis and Social Sciences Journal, 1-8.

Davy, Kate. (1995). "Outing Whiteness: A Feminist/Lesbian Project." Theatre Journal 47.2: 189.

Gaeini, M. Basirizadeh, F. (2019). The Role of social Identity in James Joyce`s Dubliners within theLight of Cultural Materialism., 89-99.

Rebhorn, Matthew. (1995). "Flying Dutchman: Masochism, Minstrelsy, And The Gender Politics Of Amiri Baraka's Dutchman." Callaloo 26.3 (2003): 796-812. Sanjuan. Jr. "Hegemony and strategies of Transgression". New York press.

Raoufzadeh, N. Mohammadhosein, S. H. Birgani, S. Z. (2019). Analysis of Love, Death, Rebirth and Patriarchy in Two Contemporary Poetess Forough Farrokhzad and Sylvia Plath's Selected Poems. Budapest International Research and Critics Institute-Journal, 56-64. 